\title{
ANALISIS KESESUAIAN LAHAN KJA BUDIDAYA KERAPU DI PERAIRAN LAUT SIKAKAP KABUPATEN KEPULAUAN MENTAWAI
}

\author{
Dino Wilmansyah ${ }^{1}$, Helfia Edial ${ }^{2}$, Widya Prarikeslan ${ }^{3}$ \\ Program Studi Geografi, \\ Fakultas Ilmu Sosial, Universitas Negeri Padang \\ E-mail : dino.wilmansyah@gmail.com
}

\begin{abstract}
Abstrak
Penelitian ini bertujuan untuk mengetahui 1). sifat kimia air laut salinitas, $\mathrm{pH}$, densitas dan kecerahan yang menentukan untuk perkembangan ikan kerapu yang di budidayakan 2). kondisi fisika (suhu permukaan air, gelombang, kecepatan arus, dan kedalaman) di perairan laut Sikakap. 3).kawasan potensial kesesuaian perairan bagi pengembangan KJA kerapu di perairan laut Sikakap. Adapun metode yang digunakan ialah adalah metode Deskriptif kuantitatif. Sumber data yang digunakan dalam penelitian ini yaitu data primer dan data sekunder Metode pengumpulan data diperoleh dari hasil pengambilan data kualitas perairan di lapangan. Sehingga didapatkan hasil berupa perairan laut Sikakap dari analisis spasial yang dilakukan dapat disimpulkan bahwa sebagian besar parameter kualitas perairannya memenuhi syarat dan berpotensi untuk kegiatan budidaya laut ikan kerapu.
\end{abstract}

Kata Kunci : keramba, kualitas perairan, kesesuaian

\begin{abstract}
This study aims to find out 1). the chemical properties of seawater salinity, $\mathrm{pH}$, density and brightness are decisive for the development of grouper cultivated 2). physical conditions (water surface temperature, waves, current velocity, and depth) in the sea waters of Sikakap. 3). Potential areas of water suitability for the development of grouper KJA in the sea waters of Sikakap. The method used is descriptive quantitative method. Sources of data used in this study are primary data and secondary data Data collection methods obtained from the results of water quality data collection in the field. So that the results obtained in the form of Sikakap sea water from spatial analysis can be concluded that most of the water quality parameters meet the requirements and potential for grouper marine aquaculture.
\end{abstract}

Keywords: cage, water quality, suitability

\footnotetext{
${ }^{1}$ Mahasiswa Program Studi Geografi 2018

${ }^{2}$ Dosen Jurusan Geografi Fakultas IImu Sosial Universitas Negeri Padang.
} 


\section{PENDAHULUAN}

\begin{tabular}{llr} 
Ikan & kerapu & \multicolumn{2}{c}{ (Groupers) } \\
merupakan salah satu jenis \\
komoditas perikanan yang bernilai \\
ekonomis tinggi baik di pasar
\end{tabular} nasional maupun internasional. Ikan kerapu mempunyai nilai jual tinggi di pasar internasional, karena rasa dagingnya yang lezat dan ketersediaannya di alam mulai berkurang Jenis kerapu yang sukses dibudi-dayakan di Indonesia dan memiliki harga jual tinggi antara lain adalah: kerapu macan (Epinephelusfuscoguttatus) dan kerapu bebek (Cromileptes altivelis). (Grahadyarini, dalam Ode, 2010).

Ikan kerapu dapat dibudidayakan di karamba jaring apung (KJA), petakan kolam laut, dan di tambak. Dengan potensi lahan yang masih cukup luas dan dukungan teknologi budidaya yang telah dikuasai mulai dari pembenihan, pendederan, penggelondongan, pembesaran, serta pangsa pasar yang baik maka pengembangan budidaya ikan kerapu. Pada tahun 1990an, usaha budidaya ikan kerapu di dalam karamba jaring apung (KJA) mulai dikembangkan untuk memenuhi kebutuhan ikan kerapu. Jenis ikan kerapu yang berhasil dibudidayakan di Indonesia antara lain kerapu lumpur, kerapu tikus, dan lain-lain (persilangan kerapu macan dan kertang).

Salah satu wilayah pengembangan Karamba Jaring Apung adalah perairan laut Sikakap,
Kabupaten Kepulauan Mentawai, yang memiliki potensi sumberdaya laut yang besar dan belum dimanfaatkan optimal. Potensi sumberdaya lautnya ini sangat perlu penanganan yang baik, guna menghasilkan peluang produksi hasil budidaya yang lebih besar di masa yang akan datang. Penentuan lokasi yang tepat juga sangat menentukan bagi keberhasilan budidaya sesuai dengan jenis budidaya yang akan dilkukan.

Semua potensi yang ada di perairan laut sikakap dapat dijadikan penyangga bagi kehidupan penduduk sekitar, sekitar $65 \%$ lebih masyarakat sekitar Sikakap berprofesi sebagai nelayan. Sehingga mengakibatkan tingginya ketergantungan masyarakat terhadap sumberdaya laut yang ada. Tetapi kondisi saat ini yang terjadi adalah nelayan mengalami penurunan hasil tangkapan, karena pola penangkapan yang tidak memenuhi prosedur yang selayaknya atau bisa dikatakan penangkapan yang merusak. Hal ini dipicu karena penggunaan alat tangkap yang daya tangkapnya yang tidak efektif dan tingkat selektivitas yang rendah.

Oleh sebab itu beberapa nelayan memilih profesi sampingan sebagai pembudidaya dengan sistem keramba jaring apung, namun Permasalahan yang dihadapi oleh para pembudidaya keramba jaring apung di laut Sikakap adalah belum adanya gambaran mengenai tingkat kesesuaian dan penentuan lokasi 
yang tepat dari perairan di laut sikakap yang merupakan zona perikanan berkelanjutan. Akibatnya para pembudidaya, khususnya budidaya kerapu menentukan lokasi budidaya tidak berdasarkan informasi tentang kelayakan lahan. Hal ini menyebabkan pemanfaatan lahan tersebut tidak tepat. Upaya pemanfaatan keramba jaring apung yang terbengkalai, harus diperlukan evaluasi kesesuaian lahan peruntukan budidaya tersebut supaya tepat pemanfaatannya.

Untuk itu di butuhkan analisis kelayakan fisik perairan serta kualitas air di pulau sikakap ini apakah cocok untuk di kembangkan karamba jaring apung untuk budidaya ikan kerapu. Untuk memperoleh suatu sistem budidaya yang bisa dikembangkan berkelanjutan untuk peningkatan kesejahteraan masyarakat.

Oseanografi fisika spesialis membahas sifat-sifat fisika yang ada dilaut. Oseanografi kimia spesialis membahas proses aksi-reaksi antara molekul, unsur, ataupun campuran dalam sistem samudera yang menyebabkan perubahan zat secara reversible dan irreversible. (Prarikeslan, 2016).

Penelitian ini bertujuan untuk mengetahui kondisi parameter keseseaian perairan yang dapat menentukan perkembangan budidaya ikan kerapu berupa suhu, salinitas, Densitas, pH, kecerahan laut. Faktor lain yang harus diperhatikan adalah tinggi gelom-bang, kecepatan arus serta kedalam-an laut yang juga dapat menentukan bagi kelangsungan budidaya ikan kerapu.

\section{METODE PENELITIAN}

Jenis Penelitian

Jenis penelitian ini adalah deskriptif kuantitatif Metode kuantitatif. Metode penelitian kuantitatif dapat diartikan sebagai metode penelitian yang berlandaskan filsafat positivisme, digunakan untuk me-neliti pada populasi atau sampel tertentu.(Sugiono, 2012) teknik pengambilan sampel biasanya adalah random sampling.

\section{Tempat Penelitian}

Lokasi penelitian ini berada di perairan Kecamatan Sikakap, Kabupaten Kepulauan Mentawai. Peta lokasi penelitian dapat dilihat di bawah ini pada Gambar 1.

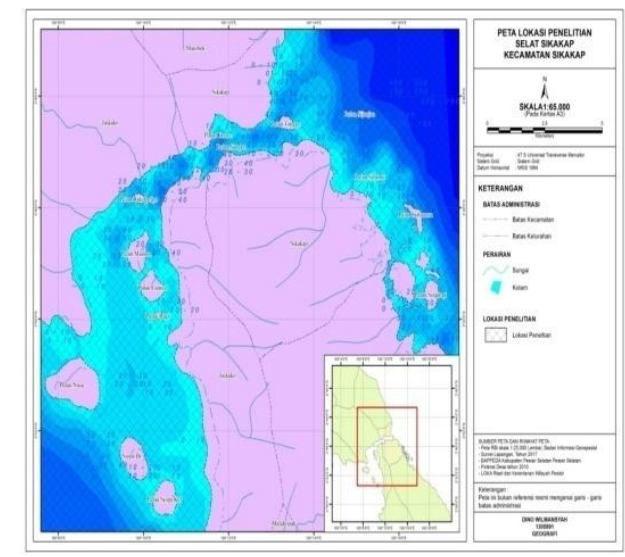

Gambar 1. Peta Lokasi Penelitian

\section{Sumber Data}

Sumber data yang digunakan untuk penelitian ini adalah dari data primer dan sekunder. Data primer 
diambil melalui pengamatan dan pengambilan sampel yang dilakulkan di lokasi penelitian. Lokasi penentuan lokasi titik sampel digunakan metode purposive sampling. Sedangkan untuk data sekunder diperlukan sebagai penunjang data primer yang telah didapatkan. Data sekunder diperoleh dari beberapa instansi yang terkait dengan penelitian.

\section{Variabel Penelitian}

Variabel yang diukur dalam penelitian ini dapat dilihat paa tabel 1 di bawah ini.

Tabel 1. Variabel Fisika-Kimia Penelitian

\begin{tabular}{lll} 
No & \multicolumn{1}{c}{ Parameter } & \multicolumn{1}{c}{ Syarat } \\
\hline 1 & Suhu & $27-32\left({ }^{\circ} \mathrm{C}\right)$ \\
\hline 2 & Kedalaman & $10-15 \mathrm{~m}$ \\
\hline 3 & Kecerahan & $\geq 5 \mathrm{~m}$ \\
\hline 4 & Salinitas & $31-34 \mathrm{ppt}$ \\
\hline 5 & $\mathrm{pH}$ & $7,5-8,5$ \\
\hline 6 & Oksigen Terlarut (DO) & $5,0 \mathrm{ppm}$ \\
\hline 7 & Kecepatan Arus & $15-30 \mathrm{~cm} /$ detik \\
\hline 8 & Tinggi Gelombang & $0,2-0,3$ meter
\end{tabular}

Sumber:Direktorat Jenderal Perikanan Budidaya 2011

\section{Teknik Pengumpulan Data}

Teknik pengambilan data yang di gunakan dalam penelitian ini adalah pengukuran langsung dilokasi berdasarkan parameter kualitas perairan. untuk mengetahui pengaruh perbedaan tempat terhadap lokasi pembesaran ikan kerapu yang dapat menentukan bagi perkembangan budidaya yang dilakukan. Pengumpulan data dilakukan secara acak yang dapat mewakili area kesesuian bagi perkembangan ikan kerapu dalam keramba jaring apung.

\section{Teknik Analisis Data}

Analisis data yang digunakan dalam penelitian ini dalah menggunakan metode matching, tahap analisis kesesuaian perairan adalah dengan membuat matrik kesesuaian yang diawali dengan mengumpulkan beberapa referensi mengenai kondisi wilayah perairan yang harus dipenuhi untuk pembudidayaan ikan kerapu sistem keramba jaring apung. Kemudian menentukan batas-batas nilai untuk setiap parameter yang memenuhi persyaratan budidaya ikan kerapu (Hartoko, 2000).

Analisis ini digunakan untuk mengetahui kesesuaian suatu wilayah untuk dijadikan sebagai lokasi yang tepat bagi daya dukung untuk keramba jaring apung. Sehingga dapat dengan mudah untuk dilakukan pengembangan budidaya ikan kerapu. 


\section{Analisa Kesesuaian Lahan}

Untuk mendapatkan kelas kesesuaian maka perlu melakukan pengelompokkan faktor yang mempengaruhi budidaya menjadi dua yaitu faktor lingkungan meliputi kedalaman, kecerahan, kecepatan arus dan faktor kualitas perairan seperti kondisi suhu, salinitas, $\mathrm{pH}$, dan densitas. Yang sesuai bagi pengembangan keramba jaring apung untuk budidaya ikan kerapu. Faktor faktor tersebut akan mempengaruhi daya tahan dan pertumbuhan serta perkembangan hidup ikan kerapu. Berikut adalah syarat pembatas dan nilai parameter kesesuaian bagi kehidupan dan perkembangan ikan kerapu yang akan dikembangkan dalam keramba jaring apung, dapat dilihat pada tabel 2 .

Tabel 2. Kesesuaian Parameter Perairan untuk Budidaya Ikan Kerapu dalam KJA Tingkat Potensi Areal

\begin{tabular}{|c|c|c|c|c|c|}
\hline \multirow[b]{2}{*}{ No } & \multirow{2}{*}{ Parameter } & & \multirow[b]{2}{*}{ Pustaka } \\
\hline & & $\begin{array}{c}\text { Sangat } \\
\text { sesuai } \\
(\mathrm{S} 1)\end{array}$ & $\begin{array}{l}\text { Cukup sesuai } \\
\text { (S 2) }\end{array}$ & $\begin{array}{c}\text { Tidak } \\
\text { sesuai } \\
\text { (S 3) }\end{array}$ & \\
\hline 1 & Suhu $\left({ }^{\circ} \mathrm{C}\right)$ & $27-32$ & $20-26$ & $\begin{array}{l}<20 \text { atau } \\
>32\end{array}$ & $\begin{array}{l}\text { Sunyoto (1994); } \\
\text { Djurjani (1999) }\end{array}$ \\
\hline 2 & Kedalaman (m) & $10-15$ & $\begin{array}{l}5-10 \text { atau } 16- \\
25\end{array}$ & $\begin{array}{l}<5 \\
>25\end{array}$ & Utojo dkk(2000) \\
\hline 3 & Kecerahan & $\geq 5$ & $3-5$ & $\leq 2$ & Radiarta (2003) \\
\hline 4 & Salinitas (ppt) & $30-35$ & $20-30$ & $\begin{array}{l}<20 \\
>25\end{array} \quad$ atau & $\begin{array}{l}\text { Sunyoto (1994); } \\
\text { Djurjani (1999) }\end{array}$ \\
\hline 5 & $\mathrm{pH}$ & $7,5-8,5$ & $6,5-7,4$ & $\begin{array}{l}<6,5 \text { atau } \\
>8,5\end{array}$ & $\begin{array}{l}\text { Sunyoto (1994); } \\
\text { Djurjani (1999) }\end{array}$ \\
\hline 6 & $\begin{array}{l}\text { Oksigen } \\
\text { Terlarut(DO) ppm }\end{array}$ & 5,0 & $4-4,9$ & $<3,9$ & Evalawati et al.,(2001) \\
\hline 7 & $\begin{array}{l}\text { Kecepatan } \\
(\mathrm{cm} / \text { detik) }\end{array}$ & $15-30$ & $\begin{array}{l}5-14 \text { atau } 36- \\
45\end{array}$ & $\begin{array}{l}<5 \text { atau }> \\
45\end{array}$ & Evalawati et al.,(2001) \\
\hline 8 & $\begin{array}{l}\text { Tinggi gelombang } \\
\text { (meter) }\end{array}$ & $0,2-0,3$ & $\begin{array}{l}0,1-0,19 \text { atau } \\
0,3-0,4\end{array}$ & $\begin{array}{l}<0,1 \\
\text { atau }>0,4\end{array}$ & $\begin{array}{l}\text { Aslan(1998); } \\
\text { Hidayat(1994) }\end{array}$ \\
\hline
\end{tabular}

Sumber:Evalawati et al., (2001)

Untuk penentuan lokasi yang sesuai peruntukan budidaya ikan kerapu dalam keramba jaring apung agar peruntukannya sesuai untuk pembudidayaan, maka dari itu pemilihan lokasinya sangat ditentukan oleh matriks kesesuaian perairan dengan memberi pembobotan dan skor pada masingmasing parameter perairan, yang mana setiap parameter akan diberi batas kesesuaian dengan nilai masing-masing, S1 untuk sangat sesuai, S2 untuk cukup sesuai, dan S3 untuk tidak sesuai. Dari hasil skring tersebutlah dapat dianalisis kesesuaian lahan yang tepat. Untuk lebih jelasnya dapat dilihat pada matrik Kesesuaian Perairan dengan pembobotan dan skoring di bawah ini pada tabel 3 . 
Tabel 3. Matrik Kesesuaian Perairan dengan Pembobotan dan Skoring

\begin{tabular}{|c|c|c|c|c|c|c|}
\hline No & Parameter & Kriteria & Batas & Nilai & Bobot & $\begin{array}{l}\text { Nilai } \\
\text { skor }\end{array}$ \\
\hline \multirow[t]{3}{*}{1} & Kedalaman (m) & $10-15$ & S1 & 5 & \multirow{3}{*}{0,2} & 1 \\
\hline & & $5-10$ atau $16-25$ & $\mathrm{~S} 2$ & 3 & & 0.6 \\
\hline & & $<5$ atau $>25$ & S3 & 1 & & 0,2 \\
\hline \multirow[t]{3}{*}{2} & Kec. Arus (m/det) & $15-30$ & S1 & 5 & \multirow{3}{*}{0,1} & 0,5 \\
\hline & & 5-14 atau $36-45$ & S2 & 3 & & 0,3 \\
\hline & & $<5$ atau $>45$ & S3 & 1 & & 0,1 \\
\hline \multirow[t]{3}{*}{3} & Salinitas (ppt) & $30-35$ & S1 & 5 & \multirow{3}{*}{0,1} & 0,5 \\
\hline & & $20-30$ & $\mathrm{~S} 2$ & 3 & & 0,3 \\
\hline & & $<20$ atau $>35$ & S3 & 1 & & 0,1 \\
\hline \multirow[t]{3}{*}{4} & Kecerahan (m) & $<5$ & S1 & 5 & \multirow{3}{*}{0,05} & 0,25 \\
\hline & & $3-5$ & $\mathrm{~S} 2$ & 3 & & 0,15 \\
\hline & & $>2$ & S3 & 1 & & 0,05 \\
\hline \multirow[t]{3}{*}{5} & Suhu $\left({ }^{\circ} \mathrm{C}\right)$ & $27-32$ & S1 & 5 & \multirow{3}{*}{0,1} & 0,5 \\
\hline & & $20-26$ & $\mathrm{~S} 2$ & 3 & & 0,3 \\
\hline & & $<20$ atau $>32$ & S3 & 1 & & 0,1 \\
\hline \multirow[t]{3}{*}{6} & $\mathrm{pH}$ & $7,5-8,5$ & S1 & 5 & \multirow{3}{*}{0,05} & 0,25 \\
\hline & & $6,5-7,4$ & $\mathrm{~S} 2$ & 3 & & 0,15 \\
\hline & & $<6,5$ atau $>8,5$ & S3 & 1 & & 0,05 \\
\hline \multirow[t]{3}{*}{7} & $\mathrm{DO}(\mathrm{mg} / \mathrm{l})$ & 5,0 & S1 & 5 & \multirow{3}{*}{0,2} & 1 \\
\hline & & $4-4,9$ & S2 & 3 & & 0.6 \\
\hline & & $<3,9$ & S3 & 1 & & 0,2 \\
\hline \multirow[t]{3}{*}{8} & Tinggi Gelombang (m) & $0,2-0,3$ & S1 & 5 & \multirow{3}{*}{0,2} & 1 \\
\hline & & $0,1-0,19$ atau $0,3-0,4$ & S2 & 3 & & 0.6 \\
\hline & & $<0,1$ atau $>0,4$ & S3 & 1 & & 0,2 \\
\hline
\end{tabular}

Sumber: Hasil modifikasi dalam Hasnawiya, 2012

Berdasarkan nilai skor setiap parameter untuk itu dilakukan penilaian untuk menentukan kelas kesesuaian untuk budidaya ikan kerapu yaitu. Masing - masing kelas kesesuaian terdiri dari S1 yaitu untuk perairan yang sesuai, S2 untuk perairan yang cukup sesuai dan S3 untuk perairan yang tidak sesuai sehingga didapatlah hasil dari pembobotan dan skoring dari semua parameter kualitas perairan yang ada tersebut dapat menentukan bagi pembudidayaan dan pengembangan ikan kerapu dalam keramba jaring apung.

Tabel 4. Penentuan Kriteria Kesesuaian Berdasarkan Interval Kelas

\begin{tabular}{lll} 
No & Kisaran Nilai & \multicolumn{1}{c}{ Keterangan } \\
\hline 1 & $4,25-5$ & $\begin{array}{l}\text { Sangat sesuai (S1), perairan tidak mempunyai faktor pembatas yang } \\
\text { berarti }\end{array}$ \\
\hline 2 & $3-3,24$ & $\begin{array}{l}\text { Cukup sesuai (S2), perairan mempunyai pembatas yang cukup } \\
\text { berarti sehingga perlu diperhitungkan sistem pembudidayaan yang } \\
\text { akan diterapkan }\end{array}$ \\
\hline 3 & $1-2,9$ & $\begin{array}{l}\text { Tidak sesuai (S3), perairan mempunyai faktor pembatas yang sangat } \\
\text { berat. }\end{array}$
\end{tabular}

Sumber: Hasil modifikasi Sutaman (1993) 


\section{HASIL DAN PEMBAHASAN}

\section{Kualitas Perairan}

Lingkungan perairan sebagai media hidup kultivan budidaya sangat mempengaruhi pertumbuhan dan keberlangsungan hidup ikan kerapu. Lingkungan biofisik perairan seperti kualitas perairan, kuantitas perairan, batimetri, iklim, keberadaan predator dan mikro serta makro organisme menjadi salah satu pertimbangan dalam penentuan lokasi budidaya. (Szuster and Albasri, 2010)

\section{Suhu Permukaan Perairan}

Suhu adalah salah satu parameter fisika yang sangat berperan penting mengendalikan pertumbuhan biota dan kon-disi ekosistem perairan. Peningkatan suhu mengakibatkan peningkatan viskositas, reaksi kimia, evaporasi, dan volatilisasi termasuk juga menyebabkan penurunan kelarutan gas dalam air, misalnya gas $\mathrm{O}_{2}$,
$\mathrm{CO}_{2}, \mathrm{~N}_{2}, \mathrm{CH}_{4}$, dan sebagainya (Effendi, 2003). Suhu perairan yang optimal untuk budidaya ikan kerapu di keramba jaring apung adalah 27 $32^{\circ} \mathrm{C}$. Pengukuran parameter suhu perairan laut Sikakap menunjukkan kisaran 26,9 - 29,6 ${ }^{\circ} \mathrm{C}$. Berdasarkan sebaran spasial, rata-rata suhu terendah tercatat di titik sampel 3 $(26,9)$ dan tertinggi di titik sampel 7 $(29,6)$. dapat di jelaskan bahwa kondisi suhu rata-rata perairan laut sikakap sangat sesuai dengan kriteria keramba jaring apung budidaya kerapu.

Berdasarkan hasil penelitian di lapangan kondisi suhu di perairan laut Sikakap menunjukan kondisi yang sesuai dengan kriteria perameter untuk budidaya ikan kerapu di dalam keramba jaring apung. Sehingga layak untuk dilakukan kegiatan budidaya.

Untuk jelasnya dapat dilihat dari peta suhu perairan di bawah ini pada Gambar 2.

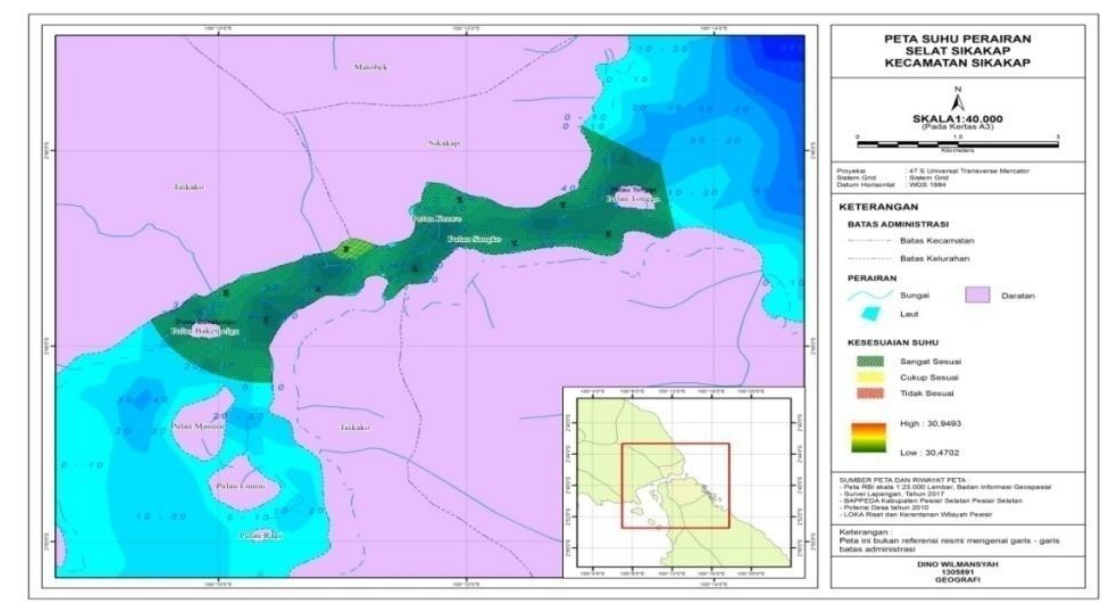

Gambar 2. Peta Suhu Perairan 
Salinitas

Salinitas optimal untuk budidaya ikan kerapu sistem keramba jaring apung adalah 30-35 ppt. Distribusi salinitas di lokasi penelitian berkisar antara 4,7$33,6 \%$. Salinitas tertinggi saat pasang yaitu pada titik sampel 8 dan terendah di titik sampel 5 dapat di simpulkan kondisi salinitas di perairan laut Sikakap sangat bervariatif sehingga tidak semua wilayah perairan memiliki salinitas yang sesuai dikembangkan untuk budidaya ikan kerapu sistem keramba jaring apung. Untuk lebih lengkapnya dapat dilihat peta tingkat salinitas perairan di bawah ini pada Gambar 3.

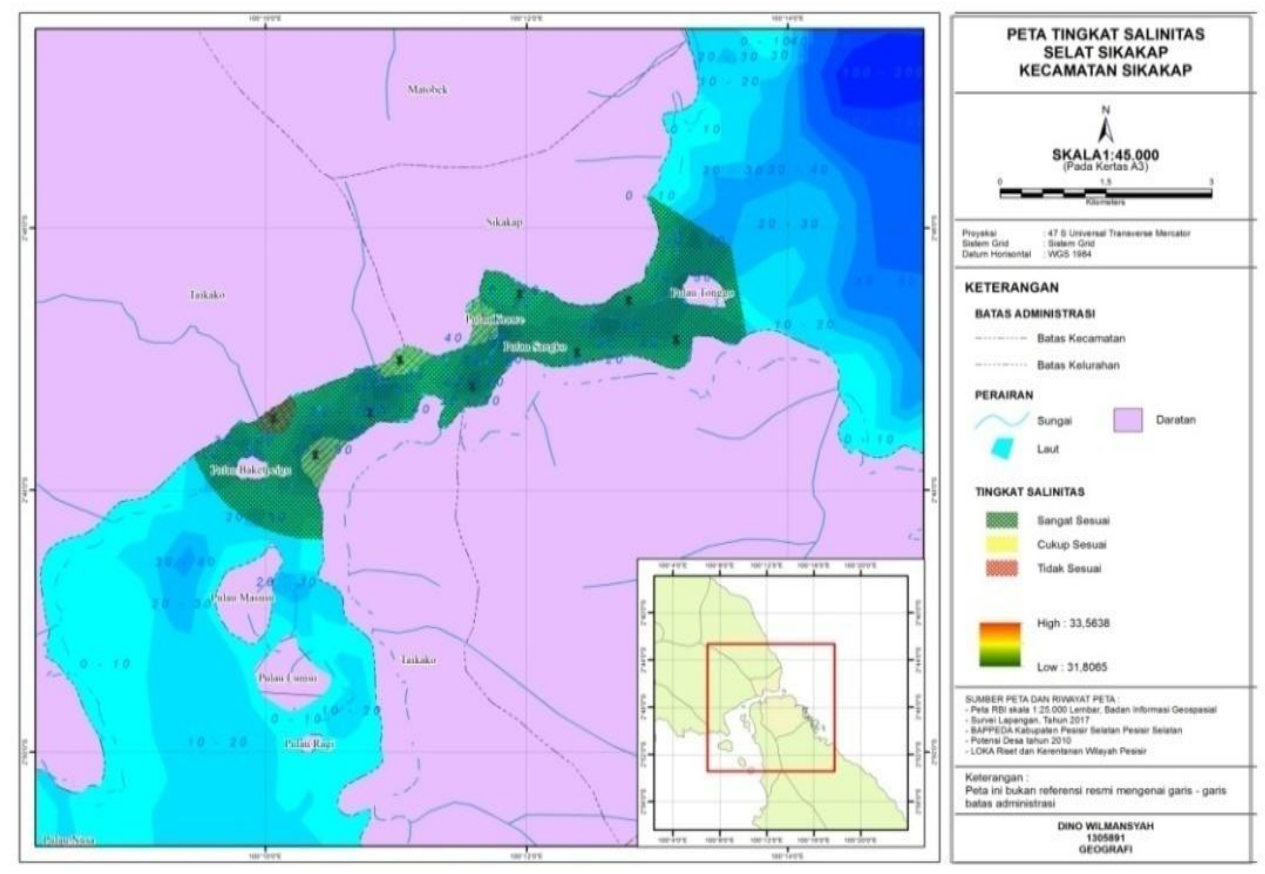

Gambar 3. Peta Tingkat Salinitas Perairan

pH

Nilai $\mathrm{pH}$ disesuaikan dengan karak-teristik alami dan jarang melebihi 7,8-8,3. Kisaran pH untuk budidaya laut adalah 7,5 - 8,5 (Direktorat Jendral Perikanan Budidaya 2011). pH yng tepat akan menentukan keberlangsungan hidup dan perkembangan ikan kerapu yang akan di budidayakan. Kisaran $\mathrm{pH}$ dari keseluruhan titik sampel pengamatan di perairan laut Sikakap adalah 7,01-7,85. dapat di simpulkan bahwa konsentrasi ph perairan laut sikakap relatif sangat sesuai untuk kegiatan budidaya ikan kerapu sistem keramba jaring apung karena tidak ada perbedaan yang signifikan antar stasiun penelitian. untuk Peta tingkat $\mathrm{pH}$ perairan dapat dilihat di bawah ini pada Gambar 4. 


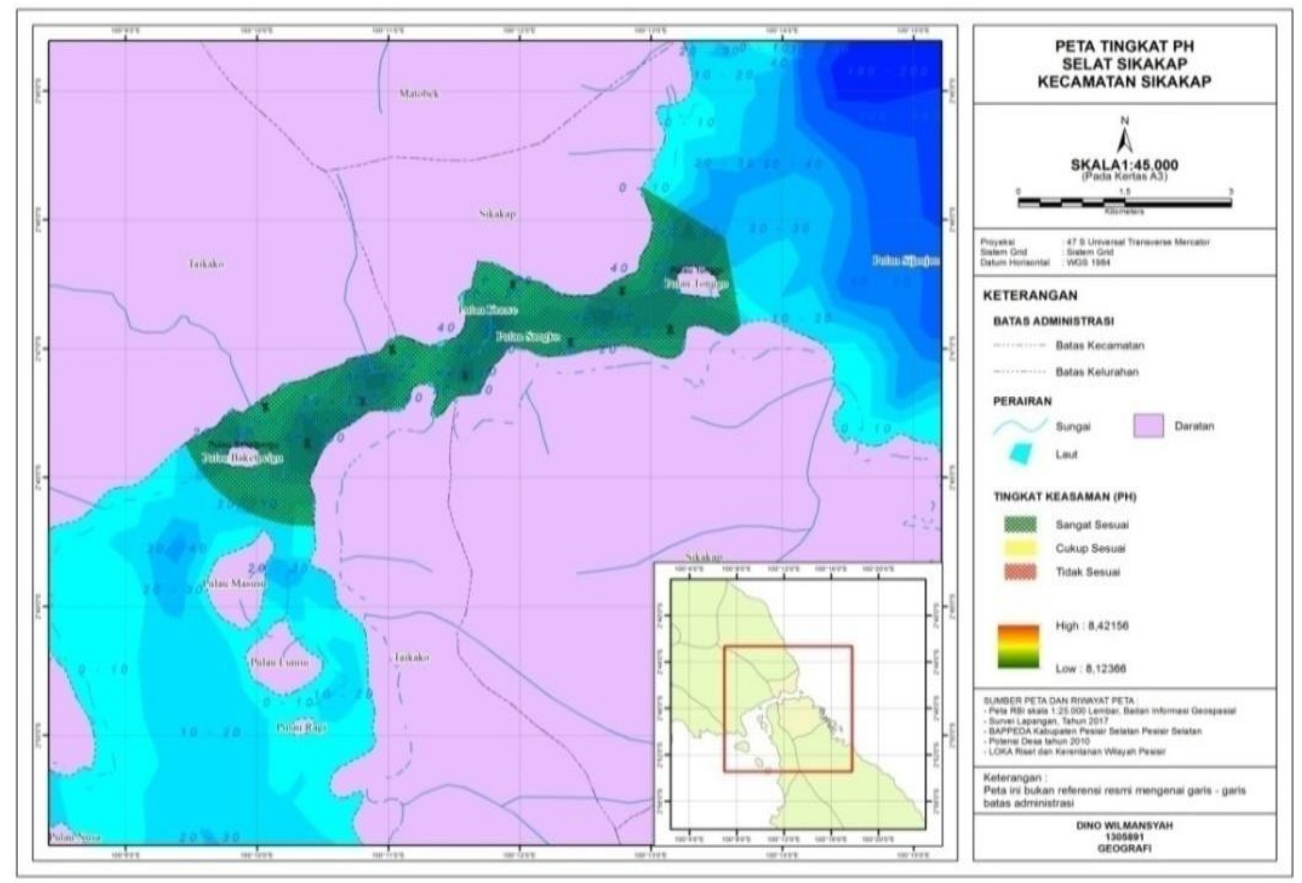

Gambar 4. Peta Tingkat $\mathrm{pH}$ Perairan.

\section{Kecerahan}

Kecerahan menunjukkan kemampuan penetrasi cahaya kedalam perairan. Tingkat penetrasi cahaya sangat dipe-ngaruhi oleh partikel yang tersuspensi dan terlarut dalam air sehingga mengurangi laju fotosintesis. Menurut Selano (2009) bahwa variasi nilai kecerahan sangat dipengaruhi oleh kondisi musim dengan kecerahan minimum terjadi pada saat musim timur.

Kondisi optimal kecerahan suatu perairan untuk kegiatan budidaya adalah >5m (Direktorat Jendral Perikanan Budidaya 2011). Kecerahan perairan laut sikakap berkisar antara 2 - 12 meter, Sebaran kecerahan tertinggi yaitu di titik sampel 10 sedangkan di titik sampel
3 memperlihatkan nilai kecerahan yang terendah.

Kecerahan perairan dari hasil penelitian masih sagat baik untuk budidaya perikanan. kecerahan pada perairan laut sikakap bervariasi dengan rata-rata beberapa wilayah dapat di jadikan lokasi yang sasuai untuk budidaya ikan kerapu sistem keramba. Perairan ini di kategorikan cukup subur dan baik untuk pembesaran karena kondisi tersebut menyebabkan cepatnya perrkembangan organisme penempel seperti lumut, cacing, dan kekerangan yang baik untuk keberlangsungan hidup ikan kerapu dalam keramba jaring apung. Untuk lebih lengkapnya dapat dilihat dari peta tingkat kecerahan perairan di bawah ini pada Gambar 5 . 


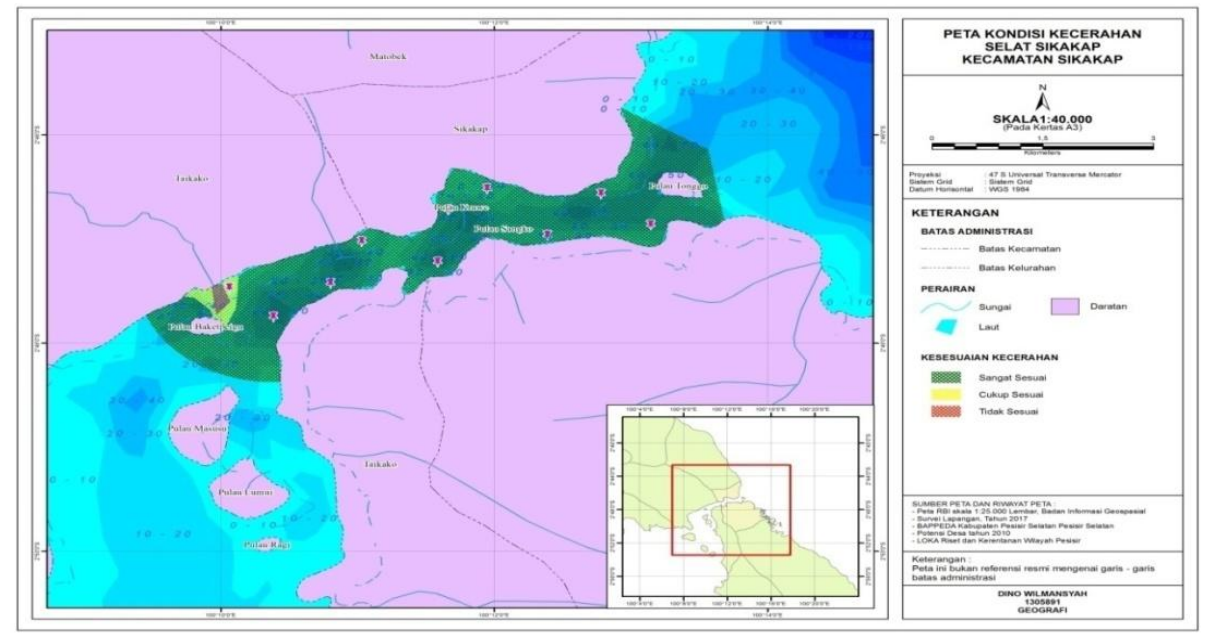

Gambar 5. Peta Tingkat Kecerahan Perairan.

\section{Oksigen Terlarut (DO)}

Kadar oksigen terlarut (Dissolved-Oxygen) berfluktuasi secara musiman, tergantung pada pencampuran (Mixing) dan pergerakan (Turbulence) massa air, aktivitas fotosintesis, respirasi dan limbah (Effluent) yang masuk ke badan air (Effendi, 2003). Konsumsi oksigen berbeda pada tiap spesies ikan dimana ikan golongan pelagic seperti kakap membutuhkan lebih banyak dibandingkan golongan demersal seperti ikan kerapu.
Konsentrasi oksigen terlarut bagi biota laut adalah 5-8 ppm. (Chou and Lee, 1997 ; KLH, 2004) Berdasarkan hasil pengamatan bahwa oksigen terlarut di perairan sikakap bervariasi dan juga dapat berfluktuatif, beberapa stasiun pengamatan memiliki oksigen terlarut yang rendah yang kurang susuai untuk budidaya ikan kerapu sistem keramba jaring apung. Berikut dapat dilihat di bawah ini peta Densitas Oksigen (DO). pada Gambar 6.

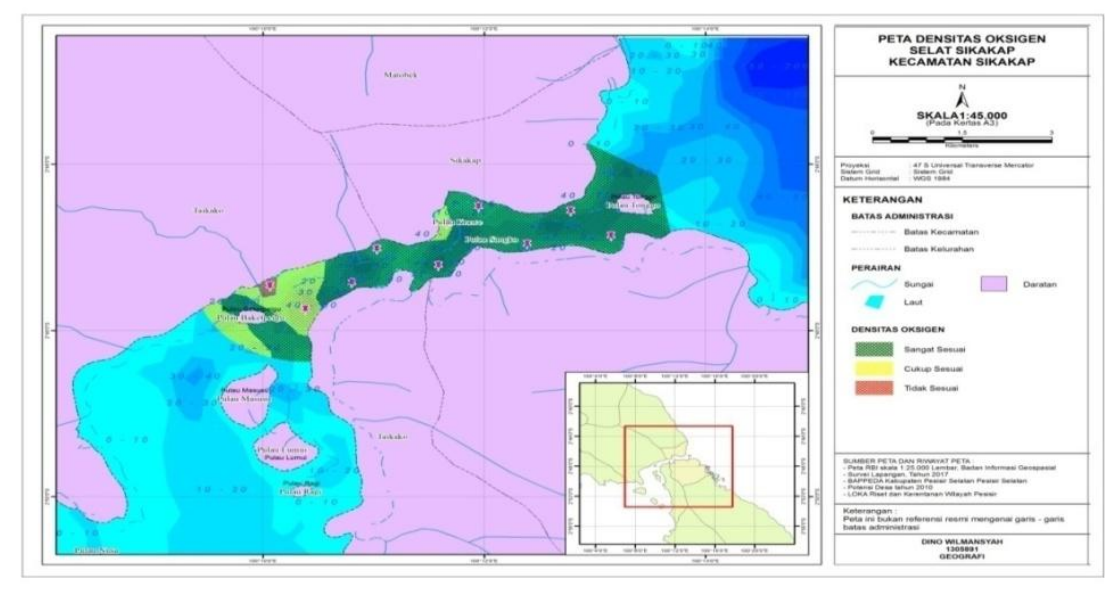

Gambar 6. Peta Densitas Oksigen (DO) Perairan. 


\section{Kedalaman}

Kedalaman menjadi salah satu faktor penting dalam budidaya ikan kerapu. Kedalaman Suatu Perairan Mempengaruhi Tingkat Penetrasi Cahaya, Akumulasi Sisa Pakan Dan Penempatan Lokasi Keramba Jaring Apung. Lokasi yang dangkal akan lebih mudah terjadinya pengadukan dasar akibat dari pengaruh gelombangyang akan menimbulkan kekeruhan. Kedalaman Maksimum Disarankan Tidak Lebih Dari 20 M Untuk Memudahkan Dalam Memposisikan Jangkar Pemberat (ChouAnd Lee, 1997).

Data kedalaman yang didapat yang telah diolah kembali dapat dijelaskan bahwa kedalaman di perairan laut Sikakap ini bervariasi dari bibir pantai hingga kelaut lepas pantainya sedangkan untuk kesesuainnya peruntukan keramba jaring apung budidaya ikan kerapu kategori sangat sesuai rata-rata disepanjang selat dan garis pantai itu cocok untuk keramba jaring pung dan juga ada beberapa titik yang cukup sesuai untuk keramba jaring apung dengan syarat, sedangkan untuk kategori tidak sesuai rata-rata berada di arah laut lepas dengan kedalaman lebih dari $25 \mathrm{~m}$ sesuai dengan parameter persyaratan budidaya ikan kerapu. Untuk lebih jelasnya dapat dilihat dari peta kedalaman di bawah ini pada Gambar 7.
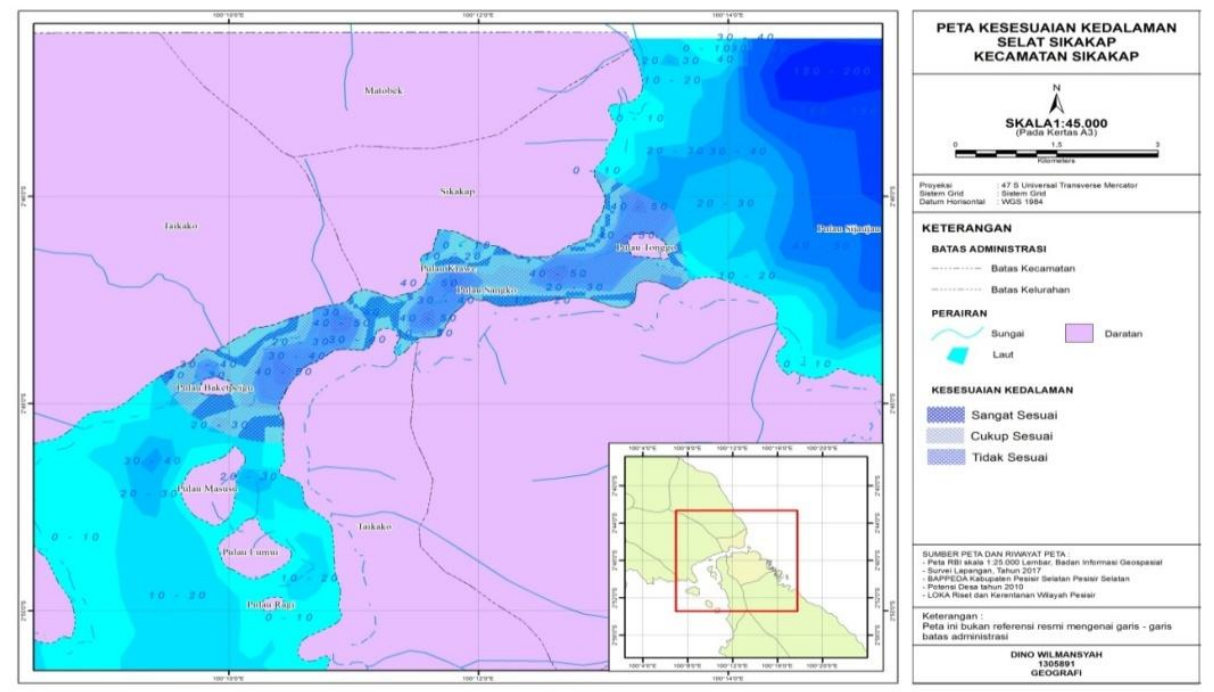

Gambar 7. Peta Kesesuaian Kedalaman Perairan.

\section{Kecepatan Arus}

Peranan arus dalam budidaya ikan laut dengan sistem keramba jaring apung sangat penting, antara lain selain sebagai sirkulasi air di dalam unit keramba, membersihkan timbunan sisa metabolisme biota kultur, membawa oksigen terlarut serta dapat mengurangi organisme penempel (biofouling) (Kordi, 2011). organisme penempel akan lebih banyak menempel pada jaring bila 
kecepatan arus dibawah $15 \mathrm{~cm} / \mathrm{dt}$ sehingga akan mengurangi sirku-lasi air dan oksigen (Mayunar dkk,1995).

Dari data kecepatan arus yang didapat dari Badan Meteorologi Klimatologi Dan Geofisika dapat dilihat bahwa kecepatan arus di perairan laut sikakap berada pada kisaran $5-15 \mathrm{~cm} / \mathrm{d}$ pada $00 \mathrm{UTC}$ hingga 12 UTC yang artinya cenderung stabil dan sesuai untuk keramba jaring apung budidaya ikan kerapu berdasarkan parameter kesesuain peruntukannya.

Berikut dibawah ini dapat dilihat sebaran kecepatan arus dari data Badan Meteorologi Klimatilogi dan Geofisika. (Gambar 8)

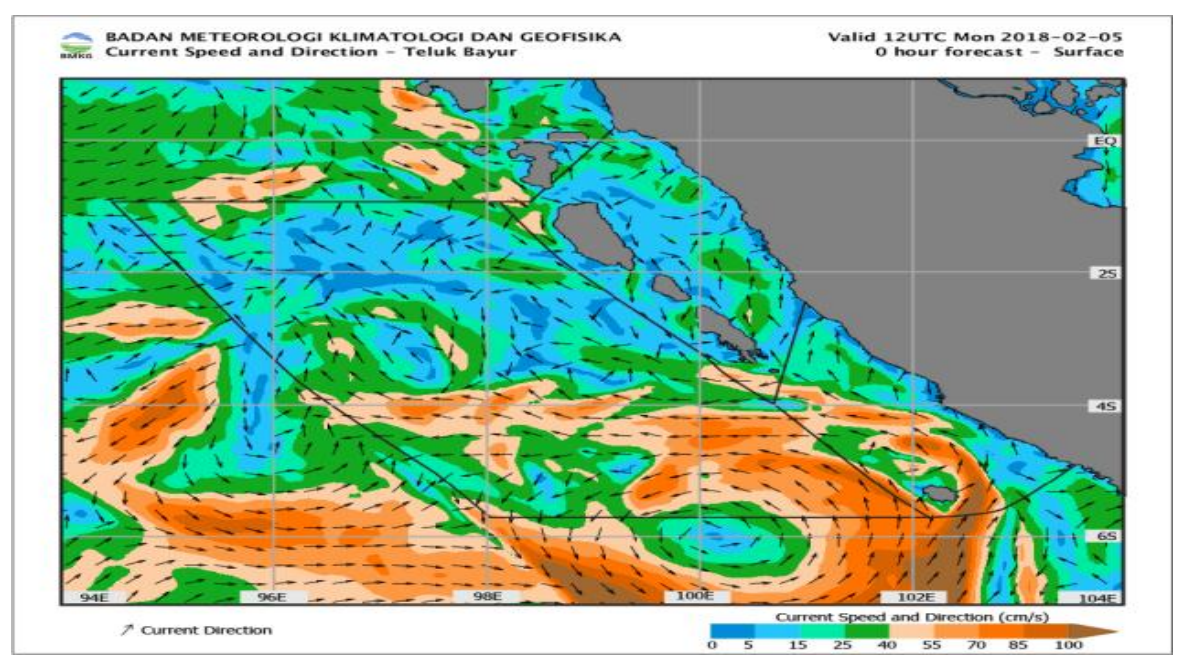

Gambar 8. Kecepatan Arus

\section{Tinggi Gelombang}

Perairan yang dipilih harus bebas dari hempasan gelombang besar dan angin yang kuat. Karena perairan terbuka dapat merusak konstruksi sarana pembesaran (rakit) dan dapat mengganggu aktifitas budidaya. Tinggi gelombang untuk pembesaran kerapu tidak lebih dari 0,5 meter baik pada musim barat maupun timur.

Berdasarkan data yang didapat dari Badan Meteorologi Klimatologi
Dan Geofisika dapat dilihat bahwa tinggi gelombang di perairan laut Sikakap pada 06 UTC, 15 UTC, dan 21 UTC menunjukan tinggi gelombang kisaran $0-0,5 \mathrm{~m}$. Yang artinya dapat di kategorikan sangat sesuai dan cukup sesuai untuk keramba jaring apung budidaya ikan kerapu sesuai dengan parameter kesesuainnya. Untuk lebih lengkapnya dapat dilihat dari gambar dibawah ini (Gambar 9). 


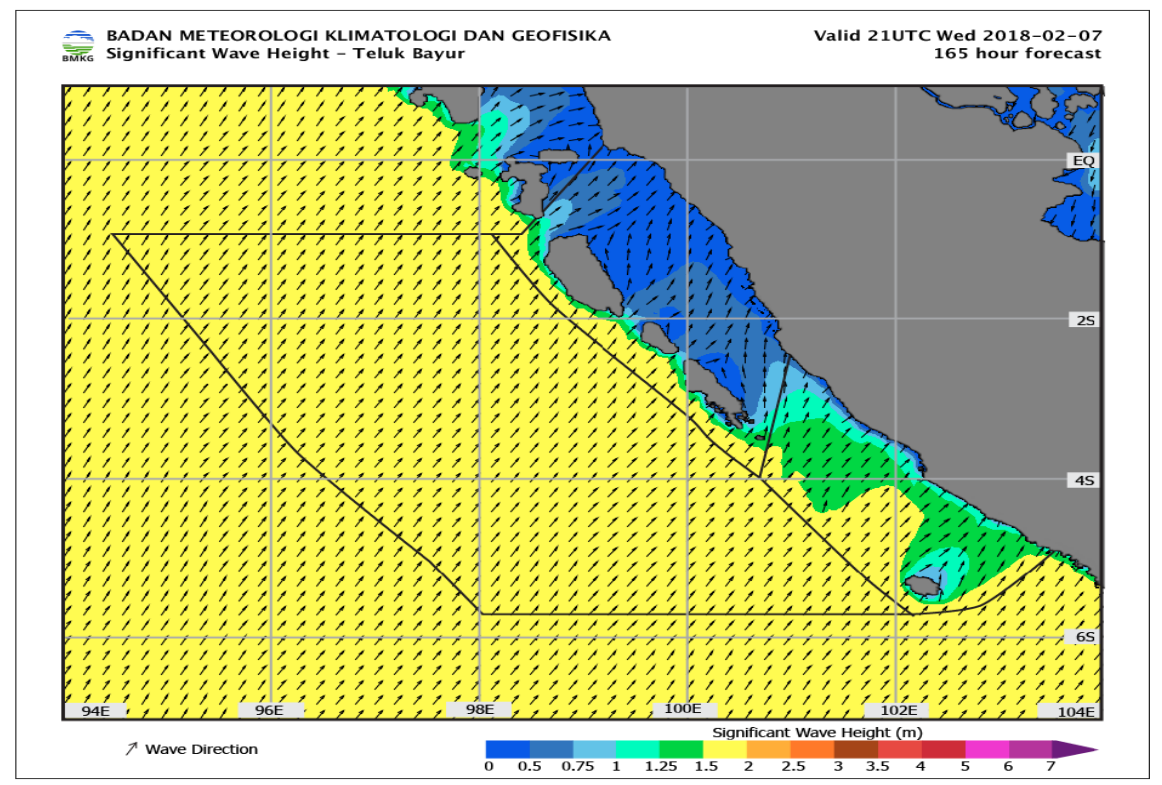

Gambar 9. Tinggi Gelombang

\section{Pembahasan}

\section{Kodisi Kimia Perairan}

Faktor lingkungan perairan sangat mempengaruhi kehidupan ikan kerapu, berdasarkan temuan penelitian kondisi perairan laut sikakap mempunyai kondisi parameter kimia yang cukup baik bagi penunjang kehidupan budidaya ikan kerapu di dalam keramba jaring apung.

Oleh karena itu pembudidaya harus benar - benar memperhatikan kondisi yang sesuai untuk parameter kimia pada perairan ini sebab tidak semua wilayah di perairan ini memiliki kondisi yang sesuai untuk dilakukan pembudidayaan dalam keramba jaring apung dan agar pemanfaatan lahan perairan ini wilayah ini sesuai tempatnya

\section{Kondisi Fisika Perairan}

Dalam konteks pengelolaan sumberdaya pesisir, pemanfaatan kawasan juga harus mempertimbangkan kondisi Fisika Pada perairan yang cukup mempengaruhi bagi aktivitas pembudidayaan ikan kerapu dalam keramba jaring apung di perairan laut sikakap. Kedalaman merupakan salah satu faktor penting dalam budidaya ikan kerapu dengan sistem keramba jaring apung. Karena dapat mempengaruhi tingkat penetrasi cahaya, akumulasi sisa pakan dan penempatan lokasi keramba jaring apung. Kondisi kedalaman pada perairan ini bervariasi yang artinya harus selektif untuk pemilihan lokasi pembudidayaan. Pemilihan lokasi budidaya laut yang dilakukan dengan benar, merupakan langkah awal keberhasilan budidaya. 


\section{Penentuan Lokasi Potensi Budidaya}

Lokasi keramba jaring apung yang tepat tentunya akan mempengaruhi perkembangan ikan kerapu yang akan di budidayakan. Untuk memperoleh lokasi yang sesuai untuk kegiatan budidaya ikan kerapu adalah dengan melihat dari peta kesesuaian lahan yang didapat dari hasil intersect parameter kesesuaian perairan dengan kedalaman laut. Kedalaman laut menjadi faktor penting dalam penempatan keramba jaring apung yang tepat.

Hasil scoring dan pemberian bobot dari data kualitas perairan parameter fisika dan kimia yang di intersect dengan kedalaman perairan, maka dapat dihasilkan gambaran peta kesesuaian lahan untuk pengembangan budidaya ikan kerapu dalam keramba jaring apung, yang di bagi menjadi tiga kelas kesesuaian yaitu: Sesuai (S1) wilayah ini sangat potensial dikembangkan pembudidayaan ikan kerapu sistem keramba jaring apung, karena memenuhi persyaratan kelayakan hidup ikan kerapu, Cukup Sesuai (S2) wilayah ini cukup sesuai dimanfaatkan untuk pengembangan budidaya ikan kerapu di dalam keramba jaring apung, tetapi wilayah ini mempunyai batasan untuk budidaya karena ada beberapa parameter perairan yang memerlukan perhatian khusus untuk meningkatkan hasil budidaya ikan kerapu dalam keramba jaring apung. Dan Tidak Sesuai (S3) adalah wilayah yang tidak sesuai untuk dilakukan pembudidayaan dan pengembangan keramba jaring apung untuk budidaya ikan kerapu karena tidak memenuhi persyaratan teknis sesuai parameter perairan untuk budidaya sehingga lahan tersebut tidak dapat dimanfaatkan sama sekali. Berikut adalah peta kesesuaian lahan berdasarkan hasil skoring dan pembobotan. Dapat dilihat pada Gambar 10.

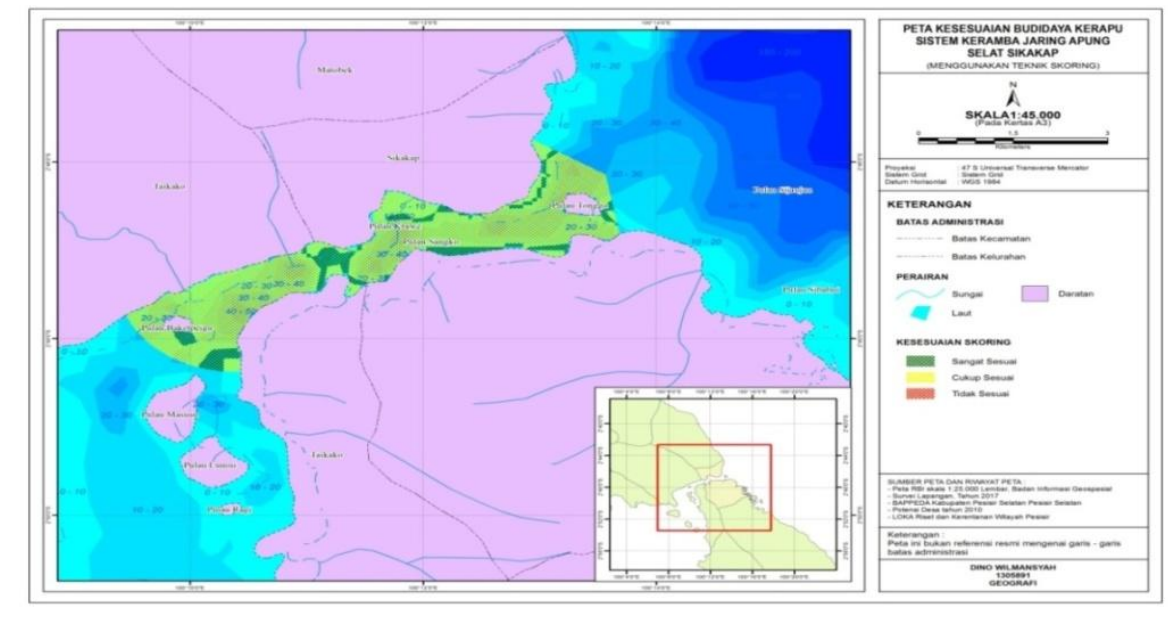

Gambar 10. Peta Kesesuaian Lahan Dengan Metode Skoring 
Dari hasil penilaian tingkat kelayakan budidaya di lokasi penelitian menunjukan bahwa sumberdaya lahan untuk budidaya ikan kerapu di perairan laut sikakap yang berpotensi dikem-bangkan S1 seluas 2.129,911 ha, sedang-kan luas budidaya yang termasuk dalam kelas cukup sesuai atau sesuai untuk dikembangkan jadi lokasi kegiatan budi-daya ikan kerapu dengan syarat S2 men-capai
2.463,767 ha, dan untuk luasan wilayah yang tidak sesuai untuk dikem-bangkan budidaya ikan kerapu sistem keramba jaring apung seluas 1.561,511 ha.

Berikut adalah peta kesesuaian lahan dari perairan laut sikakap berdasarkan hasil matcing dapat dilihat pada Gambar 11 di bawah ini.

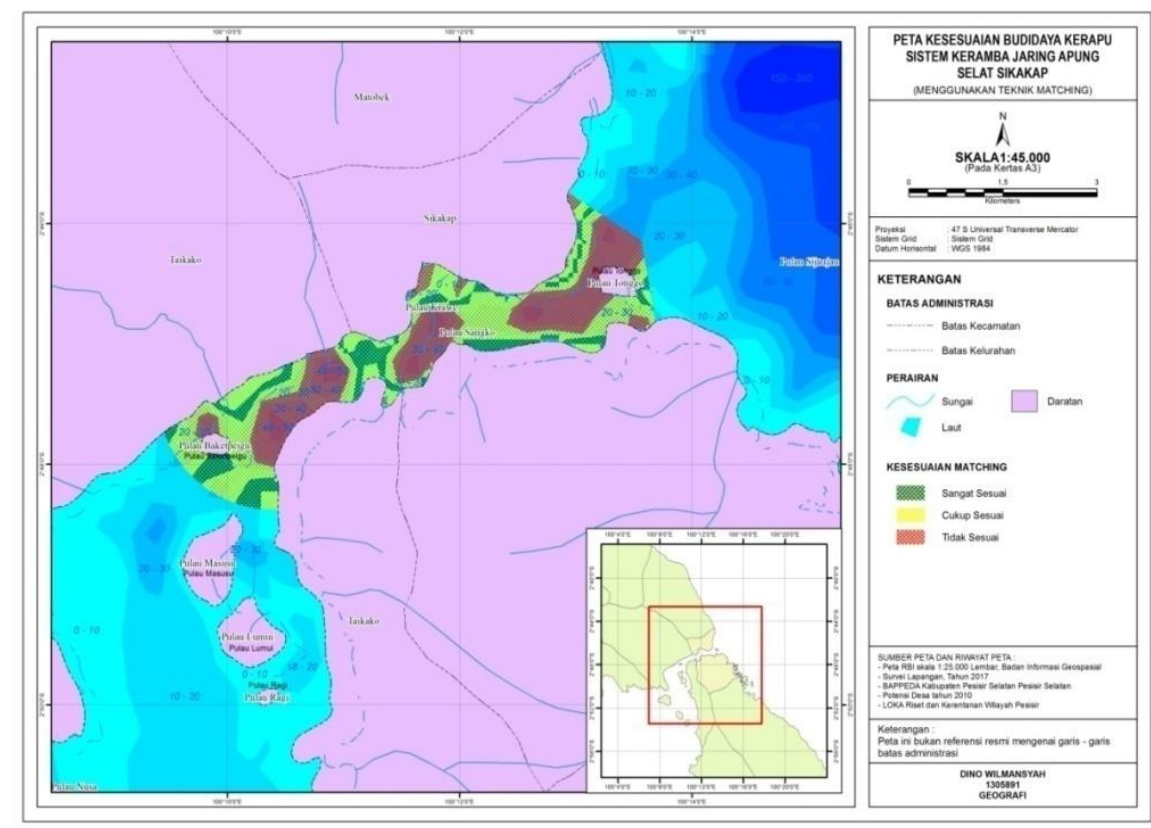

Gambar 11. Peta Kesesuaian Lahan Dengan Metode Matching.

Dari peta diatas dapat dijelaskan bahwa perairan yang berwarna hijau adalah perairan yang memenuhi syarat untuk pembudidayaan ikan kerapu dalam keramba jaring apung, sedangkan yang berwarna kuning cukup sesuai untuk pembudidayaan dengan perlakuan khusus, dan untuk yang berwarna merah merupakan wilayah yang tidak sesuai untuk dikembangkan budidaya ikan kerapu dalam keramba jaring apung.

Dengan demikian dapat disimpulkan bahwa perairan laut Sikakap memiliki sumberdaya lahan perikanan budidaya laut yang sangat potensial dikembangkan untuk 
budidaya ikan dalam karamba jaring apung. Dengan tetap memperhatikan prinsip kelestarian dan keberlanjutan dimasa yang akan datang. Sehingga kualitas perairan akan tetap terjaga. Untuk itu sebaiknya potensi lahan perairan ini tidak manfaatkan seluruhnya agar tidak terjadi penurunan kualitas perairan yang tidak hanya akan mengganggu pembudidayaan tetapi juga akan mengganggu aktifitas lainnya seperti pelayaran, pariwisata, olahraga dan lain-nya. Sehingga butuh di bangun zonasi pemanfaatan wilayah peruntukan masing-masing.

\section{KESIMPULAN}

1. Perairan laut sikakap memiliki karakteristik wilayah perairan yang berpotensi untuk untuk pengembangan budidaya laut terutama ikan kerapu.

2. Pemilihan lokasi kegiatan budidaya sesuai dari gambaran spasial kesusuaian lahan yang menunjukan perairan laut sikakap memenuhi syarat untuk budidaya ikan kerapu sistem keramba jaring apung menjadi penentu untuk pengembangan biota yang akan di budidayakan.

3. Penentuan jumlah dan letak keramba yang sasuai dapat menentukan target produksi dalam pengembangan usaha budidaya yang dilakukan.

\section{DAFTAR PUSTAKA}

Direktorat Jenderal Perikanan Budidaya, 2011. Petunjuk Teknis Budidaya Ikan Kerapu. Jakarta.

Chou, R., Lee, H.B., 1997. Commercial Marine Fish Farming in Singapore. Aquaculture Research 28, 767776

Direktorat Produksi, Ditjen Perikanan Budidaya, 2008. Petunjuk Teknis Budidaya Ikan Kerapu. Jakarta.

Effendi, H. 2003. Telaah Kualitas Air Bagi Pengelolaan Sumber Daya dan Lingkungan Perairan. Kanisius, Yogyakarta. P 258

Evalawati, M. Meiyana dan T. W. Aditya. 2001. Modul Pembesaran Kerapu Macan (Epinephelus Fuscogutattus) Di Keramba Jaring Apung. Balai Besar Pembangunan Budidaya Laut Lampung. Direktorat Pengembangan Sumber Daya Kelautan Dan Perikanan. Lampung.

Hartoko, a. 2000. Modul Teknologi Pemetaandinamis Sumberdaya Ikan Kerapu Macan Melalui Analisis Terpadu Karakter Oseanografi dan data satelit NOAA, Landsat_TM dan SeaWIFS_GSFC di Perairan Laut Indonesia. Kantor Menteri Negara Riset dan Teknologi, Dewan Riset Nasional. Jakarta. 
Hasnawiya. 2012. Studi Kesesuaian Lahan Budidaya Ikan Kerapu Dalam Keramba Jaring Apungdengan Aplikasi Sistem Informasi Geografis Di Teluk Raya Pulau Singkep, Kepulauan Riau. Journal of Aquaculture Management and Technology, 1(1) : 87-101

Ode, Alifatri La. 2010. Analisa Daya

Dukung Lahan Untuk Pengembangan Budidaya Kerapu Di Perairan Tambak Kecamatan Cilebar, Karang Districk. Bogor. Jurnal Pertanian Indonesia (JIPI).

KLH. 2004. Keputusan Menteri Negara Lingkungan Hidup Nomor 51 Tahun 2004 Tentang Baku Mutu Air Laut.

Kordi, M.G.K. 2011. Marikultur prinsip dan praktik budidaya laut, 1st ed. Penerbit ANDI. Ypgyakarta. P 6161.

Mayunar, Purba R, Imanto PT. 1995. Pemilihan Lokasi untuk Budidaya Ikan Laut. Prosiding Temu Usaha Pemasyarakatan Teknologi Keramba Jaring Apung bagi Budidaya Laut. Pusat Penelitian dan Pengembangan Perikanan. Kerjasama antara Badan Penelitian dan Pengembangan Pertanian-Forum Komunikasi Penelitian dan Pengembangan Agribisnis (FKKPA). Jakarta 12 - 13 April, No. 38: 179 187.
Prarikeslan, Widya. 2016. Oseanografi. Jakarta:Kencana. Selano, D.A.J. 2009. Analisis Hubungan Antara Beban Pencemaran dan Konsentrasi Limbah Sebagai Dasar Pengelolaan Kualitas Lingkungan Perairan Teluk Ambon Dalam. Disertasi. Sekolah Pascasarjana. Institut Pertanian Bogor. Bogor p 373.

Sugiono. 2012. Metode Penelitian Kuantitatif, Kualitatif dan RD. Alfabeta Bandung.

Sutaman. 1993. "Petunjuk Praktis Pembenihan Udang Windu Skala Rumah Tangga". Yogyakarta: Penerbit Kanisius Szuster, W.B., Albasri, H. 2010. Site Selection for Grouper Mariculture in Indonesia. Internasional Journal of Fisheries and Aquaculture 2 (3), 87-92 